\title{
Mesenchymal Stem/Stromal Cell-Derived Extracellular Vesicles and Their Potential as Novel Immunomodulatory Therapeutic Agents
}

\author{
Verena Börger ${ }^{*}+$ (D), Michel Bremer ${ }^{\dagger}$, Rita Ferrer-Tur, Lena Gockeln, Oumaima Stambouli, \\ Amina Becic and Bernd Giebel * \\ Institute for Transfusion Medicine, University Hospital Essen, University Duisburg-Essen, Virchowstr. 179, \\ 45147 Essen, Germany; michel.bremer@uk-essen.de (M.B.); rita.ferrertur@uk-essen.de (R.F.-T.); \\ lena.gockeln@gmx.de (L.G.); Oumaima.Stambouli@ruhr-uni-bochum.de (O.S.); \\ Amina.Becic@ruhr-uni-bochum.de (A.B.) \\ * Correspondence: verena.boerger@uk-essen.de (V.B.); bernd.giebel@uk-essen.de (B.G.); \\ Tel.: +49-201-723-83038 (V.B.); +49-201-723-4204 (B.G.) \\ + These authors contributed equally to this work.
}

Received: 15 June 2017; Accepted: 30 June 2017; Published: 6 July 2017

\begin{abstract}
Extracellular vesicles (EVs), such as exosomes and microvesicles, have been identified as mediators of a newly-discovered intercellular communication system. They are essential signaling mediators in various physiological and pathophysiological processes. Depending on their origin, they fulfill different functions. EVs of mesenchymal stem/stromal cells (MSCs) have been found to promote comparable therapeutic activities as MSCs themselves. In a variety of in vivo models, it has been observed that they suppress pro-inflammatory processes and reduce oxidative stress and fibrosis. By switching pro-inflammatory into tolerogenic immune responses, MSC-EVs very likely promote tissue regeneration by creating a pro-regenerative environment allowing endogenous stem and progenitor cells to successfully repair affected tissues. Accordingly, MSC-EVs provide a novel, very promising therapeutic agent, which has already been successfully applied to humans. However, the MSC-EV production process has not been standardized, yet. Indeed, a collection of different protocols has been used for the MSC-EV production, characterization and application. By focusing on kidney, heart, liver and brain injuries, we have reviewed the major outcomes of published MSC-EV in vivo studies.
\end{abstract}

Keywords: mesenchymal stem/stromal cells; cell therapy; extracellular vesicles; exosomes; microvesicles; immunomodulation

\section{Mesenchymal Stem/Stromal Cells in Cell and Immune Therapies}

Mesenchymal stem/stromal cells (MSCs) are fibroblastoid progenitor cells, which can be raised from different tissues, e.g., bone marrow, adipose tissue and umbilical cord. Typically, in vitro, they are expanded as plastic adherent cells. Propagated MSCs contain the ability to differentiate into various cell types, such as cells of the adipogenic, chondrogenic and osteogenic lineages [1-3]. The discovery that MSCs do not express Human Leuckocyte Antigen (HLA) class II encoded antigens led to the assumption that MSCs confer only low immunogenicity if transplanted in an allogeneic setting [4-6]. Upon studying the MSCs' interaction with non-related immune cells, it turned out that, in addition to their low immunogenicity, MSCs are able to suppress the function of various immune effector cell types and to promote regulatory immune functions $[5,7,8]$. According to these features, MSCs became a very attractive cell source in regenerative medicine and immune therapy. So far, more than 800 clinical trials have been registered at the National Institute of Health (clinicaltrials.gov) aiming 
to use MSCs as novel therapeutic agents to treat an increasing number of different diseases. A large percentage of the registered clinical trials is destined to treat pathological conditions resulting in tissue loss, such as ischemic stroke and myocardial infarction, and to diseases caused by non-controllable pro-inflammatory responses, such as the steroid refractory acute graft-versus-host disease (aGvHD) or Morbus Crohn [9].

\section{MSCs Exert Therapeutic Functions in a Paracrine Manner}

Initially, MSCs were thought to exert their effects according to their multipotent differentiation capacity and by direct intercellular interactions, mainly with immune cells $[5,7,8]$. However, recent data imply that MSCs mediate their therapeutic functions in a paracrine rather than a cellular manner. In several studies, it was observed that following systemic administration, the engraftment of MSCs in damaged tissues was rather low; instead, most intravenously-applied MSCs were recovered in lungs and liver of treated subjects $[10,11]$.

To best of our knowledge, Gnecchi and colleagues were the first who showed in the example of a rat ischemic heart model that the effects of MSCs were mediated in a paracrine manner [12]. Injection of conditioned media (CM) from MSCs overexpressing the gene $A k t 1$ was sufficient to reduce acute myocardial infarction (AMI) sizes and to improve ventricular functions [12,13]. Similarly, in a porcine model for AMI, intravenous and intracoronary injections of MSC-CM significantly improved the symptoms. Mechanistically, nuclear oxidative stress and apoptosis rates were reduced, which correlated with a reduction of infarction sizes and marked improvements of systolic and diastolic cardiac performances [14]. Pointing towards a cytokine mediated effect, Lee and colleagues showed in a mouse model for AMI that intravenously administered bone marrow-derived MSCs (BM-MSC) mainly got trapped in the lungs of treated animals [10]. Proposing a paracrine mode of action, the authors have started to search for cytokines being involved in this process. As a candidate, they identified the cytokine TSG-6, which in its recombinant form was able to resemble parts of the MSCs' therapeutic effects. Underlining the importance of TSG-6 in this model, the siRNA mediated knockdown of TSG-6 expression was found to abrogate the therapeutic potential of corresponding MSCs completely [10].

In the example of an acute kidney injury (AKI) model, Tögel and colleagues showed that, although injected BM-MSCs transiently engrafted into damaged renal tissue, their beneficial effects on renal function and tubular damage were mediated by anti-apoptotic, promitogenic and vasculotropic factors. Notably, fibroblasts, which were applied as the control, failed to improve the symptoms $[15,16]$. Supporting the notion that MSCs mainly act in a paracrine manner as in AMI models, CM from BM-MSC were able to improve the kidney function in AKI rats [17]. The observation that CM from MSCs, but not that from mouse lung fibroblasts, can suppress hypoxia-induced pulmonary injury in mice indicates the existence of MSC-specific paracrine components. Since application of MSC-CM specifically blocked the invasion of macrophages in the injured lungs, a link to the immunomodulatory activities of MSC-CM was provided [18]. The observation that encapsulated BM-MSCs increased the survival rates and clinical score of GvHD mice to the same extent as systemically-administered MSCs provided further evidence that MSCs exert at least parts of their therapeutic functions by the release of immunomodulatory factors [19].

\section{MSCs Exert Their Therapeutic Effects via Microvesicles and Exosomes}

Becoming aware that MSCs act in a paracrine rather than a cellular manner, several groups started to search for the therapeutically-active components. Within the two landmark studies in the field, MSC-CM were fractioned by applying different protocols. Bruno and colleagues fractioned MSC-CM by ultracentrifugation and recovered the MSCs' activity that suppressed murine acute tubular injury within the $100,000 \times g$ pellet. Upon characterizing the pellet, vesicular structures with sizes between $80 \mathrm{~nm}$ and $1 \mu \mathrm{m}$ (mean value of $135 \mathrm{~nm}$ ) were discovered, which were deciphered as microvesicles [20]. Similar to the in vivo observed effects of MSCs, the microvesicle fraction suppressed apoptosis rates 
and increased the proliferation of tubular epithelial cells in vitro to a similar extent as the MSCs themselves. Lai and colleagues used an HPLC-driven size-exclusion method and enriched a fraction containing particles with a hydrodynamic radius of 55-65 $\mathrm{nm}$ [21]. Due to the presence of the exosomal marker proteins such as CD9, CD81 and Alix, the authors used the term exosomes for the recovered particles. Upon testing the obtained exosome fraction in a murine model for AMI, a reduction of the infarction size was observed, which resembled the effects the group had already observed for MSCs and MSC-CM in a previous study [14].

\section{Extracellular Vesicles}

Cells can release a number of different membrane-surrounded vesicles of sizes ranging from a few nanometers to several microns into their extracellular environment. Collectively, these vesicles are named extracellular vesicles $[22,23]$. Historically, the term exosomes was initially used in the vesicle field for intraluminal vesicles (ILVs), which were found to be released into the extracellular environment upon fusion of late endosomes, the multivesicular bodies (MVBs), with the plasma membrane [24]. Due to the controlled assembly of the ILVs by the endosomal sorting complex required for transport (ESCRT) machinery, ILVs are comparable in size [25]. Depending on the techniques used, the sizes of the ILVs, which are released into the extracellular environment, vary between 70-100 $\mathrm{nm}$ (when analyzed by Transmission Electron Microscopy, TEM) and 120-150 nm (when analyzed by Nanoparticle Tracking Analysis, NTA) [26]. Although excreted ILVs can be enriched by different methods [27], the resulting fractions regularly also contain vesicles of similar sizes, which do not derive from the endosomal compartment. Initially, all nanosized extracellular vesicles (EVs) were named exosomes; however, to be more precise, members of the International Society of Extracellular Vesicles (ISEV) agreed to specifically use the term exosomes for ILV-corresponding vesicles. Nowadays, vesicles that bud off the plasma membrane are named microvesicles; they can be larger than exosomes and typically have said sizes of 100-1000 nm. A third class of very prominent vesicles arises when apoptotic cells get fragmented. According to the literature, apoptotic cells form apoptotic bodies with said sizes of $500 \mathrm{~nm}$ to several microns [22,23]. However, as commonly not mentioned in the literature, apoptotic cells also form vesicles in the same size range as exosomes and microvesicles. In addition, there are plenty of other sources of membrane-surrounded vesicles with a huge collection of different names, e.g., ectosomes, oncosomes, microparticles, etc. [28]. Due to the fact that no specific exosome and microvesicle markers have been identified yet and, for now, vesicles can only be fractioned according to their sizes and/or densities, but not regarding their origin, representatives of ISEV agreed on naming all experimentally-obtained vesicles as extracellular vesicles (EVs) [22,23,29].

As initially there were no agreed methods to characterize prepared EV fractions, the ISEV published a position paper defining some minimal criteria recommended for the characterization of purified EVs [30]. This includes semi-quantitative analysis of the EVs' protein composition, commonly Western blots (WBs) for typical EV marker proteins, such as CD9, CD63, CD81, Alix or TSG101, size analysis by NTA, dynamic light scattering (DLS) or recessive pulse sensing (RPS) and analysis of their morphology regularly by TEM [30].

Starting with the discovery in 1996 that EVs released by B cells can promote T cell responses [31], it became evident that EVs constitute essential components of a newly-discovered intercellular communication system. [32]. Meanwhile, EVs have been harvested from all body fluids and were found to essentially take part in many physiological and pathophysiological processes [33]. Depending on their origin, EVs exert different functions. Maybe based on the landmark paper of Raposo and colleagues [31], the EV-mediated communication has best been investigated between tumor and immune cells and among different immune cell types. For example, mature dendritic cells have been found to release EVs promoting pro-inflammatory functions [34], while many tumor cells release EVs with anti-inflammatory and tolerance-inducing functions [32]. At the molecular level, the EVs' functional properties are reflected to the presence of specific combinations of molecules, typically mirroring unique characteristics of their cells of origin. According to these characteristics, EVs have 
been recognized as a novel class of biomarkers for a variety of different diseases, which can often be detected in liquid biopsies from early disease stages on [35]. In this context, especially the discovery that EVs carry RNAs, which can effectively modulate gene expression in the EVs' target cells, has promoted the field intensively [36-38].

\section{MSC-EVs Exert Therapeutic Functions in Different Disease Models}

Since the original description of the therapeutic potential of MSC-EVs in the AKI and MI models in 2009 and 2010 [20,21], respectively, approximately 80 original manuscripts have been published addressing the therapeutic functions of MSC-EVs in animal models. Up to now, the most addressed topics were heart, kidney, liver and brain injuries. Within the following part, this review gives a global overview of studies that have applied MSC-EVs to any of these injury models and have investigated the impacts of the applied MSC-EVs on immunobiological processes in vivo. Although our intention was to include all publications fulfilling these criteria, we would like to apologize in case we have missed any publication of relevance. Before discussing the MSC-EVs' therapeutic properties, some basic features of the studies should be compared.

\section{MSC-EV Production Strategies}

Comparable to the MSC field, the MSCs for the EV production were obtained from different tissues and raised under different culture conditions. Some groups used serum- or human platelet lysate (PL)-supplemented media, while others used serum-free media (Table 1). Moreover, the preparation of the CM for the EV isolation was also different. Most of the groups used special EV-depleted media, while others used normal expansion media (Table 1). A high variability is also reflected by the EV-isolation methods, which had been used to isolate the EVs for the functional studies, ranging from ultracentrifugation- to chromatography-based methods (Table 1). Furthermore, the obtained EVs had been characterized in variable manners. It is not our intention to discuss the different parameters, here; however, to highlight the high variability in the MSC-EV production and characterization, we have included the information in Table 1.

\section{Application of MSC-EVs in Animal Models}

Comparable to the MSC-EV production strategies and besides the fact that different animal species and strains were used as model systems, the way the in vivo studies were designed varies tremendously (Table 2). Most groups applied the MSC-EVs intravenously or intraperitoneally. However, also other application strategies were used, e.g., directly into injured tissues. Some groups applied the MSC-EVs once; while others used varying numbers of repetitive applications (up to five times; Table 2). Moreover, most of the publications deciphered the amount of the applied MSC-EVs regarding their protein concentration, which was very variable between studies. A few groups used particle numbers or cell equivalent doses to decipher their applied MSC-EV amounts. As diversely as the studies had been designed were the methods with which biological effects were characterized. A few studies searched for individual molecules that contributed to the observed effects. Several studies identified specific RNAs (mRNA and/or miRNA) as essential functional components of their applied MSC-EV fractions. However, no specific RNA or any other molecule was identified in several studies (Table 2). Remarkably, despite the high variability in the study designs, all studies observed improvements of the investigated disease/injury symptoms (Figure 1).

With respect to kidney diseases, mainly the effects of MSC-EVs on AKI were investigated. MSC-EV treatment was found to improve kidney function in these AKI models [39,40]. Specifically, MSC-EV administration was repetitively found to decrease AKI-induced oxidative stress, apoptosis and fibrosis $[17,20,39-44]$. Instead, MSC-EV treatment promotes angiogenesis and expansion of endogenous renal cells $[17,20,41-43,45]$. At the immunobiological level, MSC-EV treatment led to a reduction of pro-inflammatory and an increase of anti-inflammatory cytokines $[17,44,46]$. Related to 
this, AKI-induced invasion of macrophages and lymphocytes was suppressed in MSC-EV-treated AKI animals $[39,43,47]$.

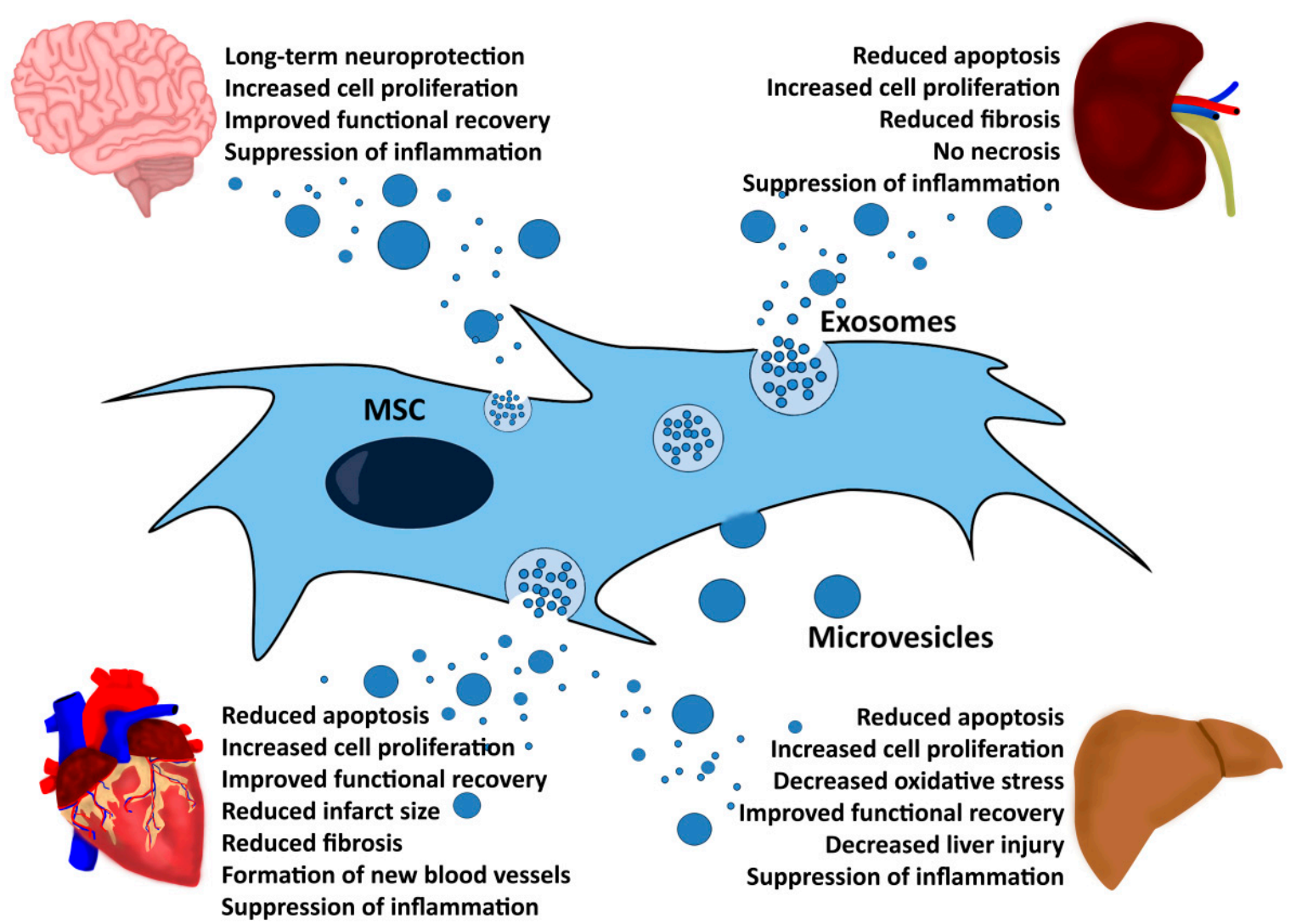

Figure 1. Overview of the MSC-EV-mediated therapeutic effects observed in animal models for kidney, heart, liver and brain injuries. MSC, mesenchymal stem cells, EV, extracellular vesicles.

Regarding the heart, the MSC-EV therapeutic impacts were mainly studied in AMI models. Several studies observed that MSC-EV treatment in AMI models led to a reduction of infarction sizes and improvement of general heart functions [21,29,48-54]. Comparable to the AKI models, MSC-EV treatment reduced fibrosis and apoptosis, but promoted angiogenesis instead [29,48-51,53,54]. Furthermore, MSC-EV treatment was found to reduce the invasion of macrophages and eventually other immune cells into the affected heart regions $[49,50]$.

The MSC-EVs' impact on liver diseases was studied in models for acute liver injury (ALI), hepatic failure and hepatic ischemia/reperfusion injury. MSC-EV treatment improved liver functions in all models and induced anti-apoptotic effects [55-59]. Like in the previous models, MSC-EV administration resulted in a decline of pro-inflammatory reactions including immune cell invasion and oxidative stress [55-57,59,60].

Regarding the brain, impacts of MSC-EV treatment were mainly studied in models for ischemic stroke and traumatic brain injury (TBI) [61-71]. In addition, we studied the therapeutic effects of MSC-EVs in a rat model for inflammation-induced preterm and a sheep model for hypoxia-induced fetal brain injury [72,73]. Almost all studies that used naive MSC-EVs showed an MSC-EV-mediated improvement of cognitive deficits or function, respectively $[62,68,69,71-73]$. Coupled to the functional recovery, more neural cells were generated in MSC-EV-treated than in control animals $[62,63,68]$. Comparable to the other organ systems discussed before, MSC-EV treatment reduced apoptosis rates in affected brains, but promoted angiogenesis and neurogenesis instead [63,66,70,71,73,74]. Both, systemic pro-inflammatory and neuro-inflammatory cues were reduced following MSC-EV treatment. 
Amongst others, the number of invading macrophages into the affected brain areas was found to be reduced $[62-64,68,70,72,73]$.

\section{MSC-EVs in the Clinics}

So far, two studies have been published in which MSC-EVs were applied to human patients. In the first study [75], MSC-EVs were administered in an allogeneic setting to a patient suffering from steroid refractory graft-versus-host disease (GvHD). Upon applying MSC-EVs in escalating doses, GvHD symptoms declined long term, and steroid doses could be reduced. Upon analyzing the immunomodulatory activity of the applied MSC-EV fraction in a mixed lymphocyte reaction (MLR) assay before MSC-EV treatment, MSC-EVs were able to suppress the number patient-derived peripheral blood cells, which secreted the pro-inflammatory cytokines IL-1 $\beta$, TNF $\alpha$ and IFN $\gamma$. During the course of the treatment and in the absence of any additionally in vitro applied MSC-EVs, the number of patient-derived peripheral blood cells, which secreted IL-1 $\beta$, TNF $\alpha$ and IFN $\gamma$, within the MLR assays declined over time. Since these data reflected the clinical GvHD symptoms, the data suggest that MSC-EVs can modulate the status of the patients' immune cells in a sustained manner. The applied MSC-EV fraction was shown to contain the anti-inflammatory cytokines TGF- $\beta$, IL-10 and HLA-G. Notably, by comparing the concentration of these cytokines in four independent MSC-EV fractions, higher levels were found in the MSC-EV fraction that was applied to the patient than in the three remaining ones. To this end, it has not been investigated whether the other MSC-EV fractions have lower immunomodulatory capabilities than the applied MSC-EV fraction. It remains an open question whether the MSC-EVs' anti-inflammatory capabilities were associated with their relatively high TGF- $\beta$, IL-10 and HLA-G levels, or whether other EV components controlled the improvement of the GvHD symptoms. However, for a time interval of more than four months, the MSC-EV therapy resulted in significant improvement of clinical GvHD symptoms of the treated patient [75].

The second study addressed the therapeutic impact of MSC-EVs in patients with chronic kidney disease (CKD) [76]. Forty patients were included in this study. Half of them were placebo treated, the other half with MSC-EVs. MSC-EVs were applied twice, for the first treatment intravenously and, for the second treatment, one week later, intra-arterial. Without showing any side effects and in contrast to the control group, the MSC-EV-treated group showed significant improvements of the kidney function as measured by a variety of different markers, i.e., the estimated glomerular filtration rates (eGFR), the urinary albumin to creatinine ratio and the blood urea and serum creatinine levels. Impacts on the immune system were studied by analyzing TGF- $\beta$, IL-10 and TNF $\alpha$ concentration in the peripheral blood. TGF- $\beta$ and IL-10 concentrations were increased massively in MSC-EV-treated patients short term (12 weeks) and were even detected in elevated levels one year after MSC-EV treatment. In contrast, the pro-inflammatory cytokine TNF $\alpha$ was decreased in the MSC-EV-treated group shortly after MSC-EV administration and remained low during the following year of observation. Upon taking biopsies from the patients' kidneys, an increased number of CD133/Ki67 tubular cells (putative cycling renal progenitor cells) was discovered in the biopsies of the MSC-EV-treated patients, but not in those of the control groups, suggesting that the MSC-EV therapy triggered the regeneration within the affected kidneys [76].

\section{MSC-EVs as a Novel Therapeutic Agent}

Despite the variability in the MSC-EV production and application, the results of the different animal models and the two clinical applications demonstrate positive therapeutic effects of MSC-EVs. So far, no side effects have been reported, implying that MSC-EVs application can in principle, be considered as safe. According to their therapeutic potential and a number of advantages over cellular therapeutics [77], several groups have started with efforts to translate MSC-EVs into the clinics. In this respect, a number of guidelines need to be fulfilled. As EVs are novel therapeutic agents, these guidelines have not been defined yet, but might at least partially be adopted from other guidelines for 
cellular therapeutics. A comprehensive overview about potential guidelines and recommendations for the production, quality assurance and application of EV-based therapeutics have recently been provided in an ISEV and European Network on Microvesicles and Exosomes in Health and Disease (ME-HaD) position paper [77].

\section{Conclusions and Perspectives}

Although MSC-EVs seem to exert positive impacts on tissue specific stem cells, promote angiogenesis and suppress oxidative stress and fibrosis (Figure 1), according to our understanding, their most important impact is to suppress pro-inflammatory responses in all disease models discussed. Supported by the findings in our ischemic stroke model that in an untreated situation, neural progenitors are not able to effectively create mature neural cells [63], we would like to speculate that pro-inflammatory environments are not permissive for endogenous stem and progenitor cells to initiate regenerative processes. To our understanding, endogenous stem and progenitor cells require a tolerogenic environment to survive and to successfully promote regeneration. Indeed, at the cellular level, it was shown, in vitro, that MSC-EVs are able to convert M1 into M2 macrophages and that EVs released by M2 macrophages can subsequently promote regulatory T-cell formation [78]. Thus, by switching pro-inflammatory into tolerogenic environments, MSC-EV administration might promote regenerative processes.

Coupled to the lack of standardization and the high variability in MSC expansion and EV purification protocols, it appears very likely that differences in experimental strategies to prepare MSC-EVs for the therapeutic setting will result in MSC-EV fractions showing different immunomodulatory properties. Furthermore, in our past and on-going work, we have experienced that, maybe attributed to the different presence of certain cytokines, MSC-EV preparations vary in their immunomodulatory activities, eventually in a donor-dependent manner [75]. Accordingly, it has to be considered that not all MSC-EV fractions provide sufficient therapeutic activities to improve the clinical symptoms of the disease to be treated. To identify MSC-EV fractions with the highest therapeutic potential, appropriate potency assays need be set up. However, to set up optimal potency assays, the mode of action of the MSC-EVs needs to be unraveled. Furthermore, it will be required to compare the in vitro activities of different MSC-EV fractions with their therapeutic potential in vivo. Considering that their effect is mainly mediated by tolerance-inducing activities, it will be interesting to learn whether MSC-EV fractions with high therapeutic potentials in one disease model will also have high therapeutic potentials in other diseases models or whether each disease model requires its own optimal MSC-EV fraction. 
Table 1. Experimental parameters of the MSC expansion and EV harvesting and characterization strategies reported for MSC-EV in vivo studies.

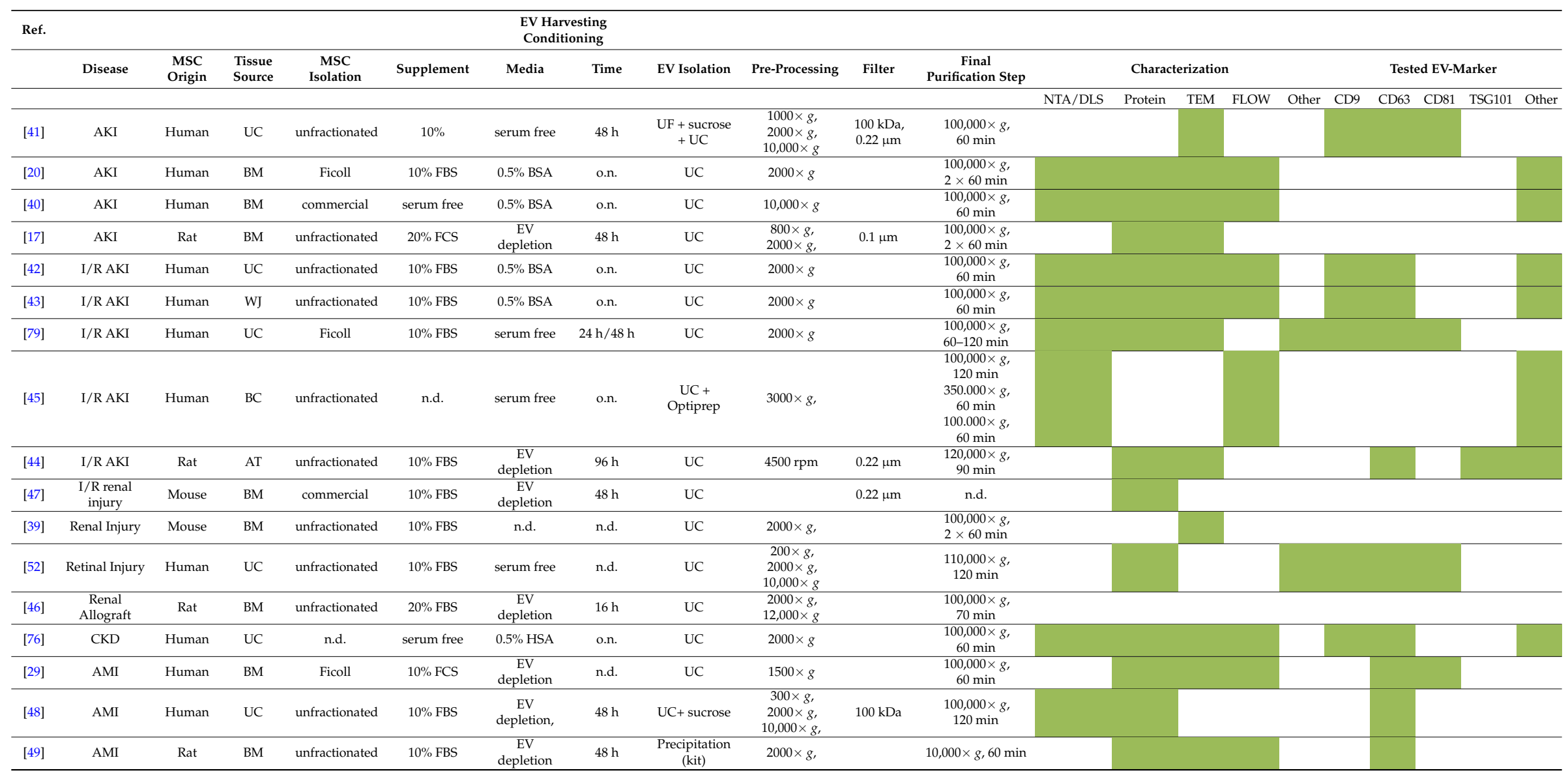


Table 1. Cont




Table 1. Cont



EV, extracellular vesicle; AKI, acute kidney injury; I/R, ischemia/reperfusion; AMI, acute myocardial injury; ALiI, acute liver injury; TBI, traumatic brain injury; SCI, subortical Stroke; GvHD, graft-versus-host-disease; ALuI, acute lung injury; UC, umbilical cord; BM, bone marrow; WJ, Wharton jelly; BC, bowman's capsule; AT, adipose tissue; ESC, embryonic stem cells; $\mathrm{MB}$, menstrual blood; iPSC, induced pluripotent cells; n.d., not defined; FBS, fetal bovine serum; FCS, fetal calf serum; PL, platelet lysate; BSA, bovine serum albumin; HSA, human serum albumin; h, hours; o.n., over night; UF, ultrafiltration; TFF, tangential flow filtration; UC, Ultracentrifugation; HPLC, high-performance liquid chromatography; PEG, Polyethylene glycol; $\mathrm{g}$, g-force; $\mathrm{kDa}$, kilo Dalton; $\mu \mathrm{m}$, micrometre; min, minutes; rpm, rounds per minute; NTA, nanoparticle tracking analysis; DLS, dynamic light scattering; TEM, transmission electron microscopy; FLOW, Flow cytometry; CD, cluster of differentiation. 
Table 2. Application and analyses schemes of MSC-EV in vivo studies.

\begin{tabular}{|c|c|c|c|c|c|c|c|c|c|c|c|c|c|}
\hline \multirow[t]{2}{*}{ Organ } & \multirow[t]{2}{*}{ Reference } & \multirow[t]{2}{*}{ Disease } & \multicolumn{3}{|c|}{ Animal } & \multirow[t]{2}{*}{$\begin{array}{l}\text { Xenogenic } \\
\text { Application }\end{array}$} & \multirow[t]{2}{*}{$\begin{array}{c}\text { Functional } \\
\text { Testing In Vitro }\end{array}$} & \multirow[t]{2}{*}{ Application } & \multirow[t]{2}{*}{ EV Dose } & \multirow[t]{2}{*}{$\begin{array}{l}\text { No. of } \\
\text { Injections }\end{array}$} & \multirow[t]{2}{*}{ Factors } & \multirow[t]{2}{*}{$\begin{array}{c}\text { Immunomodulatory } \\
\text { Effects }\end{array}$} & \multirow[t]{2}{*}{$\begin{array}{c}\text { Described Effects After MSC-EV } \\
\text { Application }\end{array}$} \\
\hline & & & Species & Strain & Gender & & & & & & & & \\
\hline \multirow{12}{*}{ Kidney } & [41] & AKI & Rat & SD & $\mathrm{f}$ & y & & Renal capsule & $200 \mu g$ & 1 & Bcl-2, Bax & & $\begin{array}{c}\text { Reduced apoptosis } \\
\text { Increased cell proliferation }\end{array}$ \\
\hline & [20] & AKI & Mouse & SCID & $\mathrm{m}$ & $\mathrm{y}$ & EV uptake & i.v. & $15 \mu \mathrm{g}$ & 1 & mRNA dependent & $\begin{array}{l}\mathrm{RNA} \text { shuttled in } \mathrm{MV} \\
\text { associated with immune } \\
\text { regulation }\end{array}$ & $\begin{array}{l}\text { Morphological recovery } \\
\text { Reduced apoptosis } \\
\text { Increased cell proliferation }\end{array}$ \\
\hline & [40] & AKI & Mouse & SCID & $\mathrm{m}$ & $\mathrm{y}$ & Apoptosis assay & i.v. & $\begin{array}{c}100 \mu g \\
100 \mu g+50 \mu g\end{array}$ & 1 or 5 & $\begin{array}{l}\text { RNA dependent, ACTB, } \\
\text { POLR2E SUMO-1 }\end{array}$ & & $\begin{array}{l}\text { Improved survival } \\
\text { Single injection: increased renal function } \\
\text { morphology and survival (although } \\
\text { negative impact in the long-term) } \\
\text { Multiple injections: decreased mortality } \\
\text { (no impact in the long-term) }\end{array}$ \\
\hline & [17] & AKI & Rat & Wistar & $\mathrm{f}$ & $\mathrm{n}$ & & i.v. & $100 \mu \mathrm{g} / \mathrm{mL}$ & 1 & mRNA dependent & $\begin{array}{l}\text { Infiltrated lymphocytes T-B } \\
\text { cell count higher, NK } \\
\text { reduced TNF } \alpha \text { transcripts } \\
\text { reduced }\end{array}$ & $\begin{array}{l}\text { Increased cell proliferation } \\
\text { No necrosis }\end{array}$ \\
\hline & [42] & I/R AKI & Rat & n.d. & $\mathrm{m}$ & $\mathrm{y}$ & & i.v. & $100 \mu \mathrm{g}$ & 1 & $\begin{array}{l}\text { RNA dependent, VEGF, } \\
\text { HIF-1 } \alpha\end{array}$ & & $\begin{array}{c}\text { Reduced fibrosis } \\
\text { Increased vessel density } \\
\text { Reduced apoptosis } \\
\text { Increased cell proliferation }\end{array}$ \\
\hline & [43] & I/R AKI & Rat & SD & $\mathrm{m}$ & $\mathrm{y}$ & & i.v. & $100 \mu g$ & 1 & miR16, miR15b, miR15a & $\begin{array}{l}\text { Reduced infiltration of } \\
\text { macrophages (CD68 +) }\end{array}$ & $\begin{array}{c}\text { Reduced apoptosis } \\
\text { Increased cell proliferation }\end{array}$ \\
\hline & [79] & I/R AKI & Rat & SD & $\mathrm{m}$ & $\mathrm{y}$ & $\begin{array}{c}\text { T-reg induction } \\
\text { T-cell } \\
\text { proliferation }\end{array}$ & i.a. & n.d. & 1 & $\begin{array}{l}\text { Apolipoprotein, } \\
\text { galectins CD73, CD90 }\end{array}$ & & $\begin{array}{c}\text { No necrosis } \\
\text { No tubular dilation } \\
\text { No cast formation } \\
\end{array}$ \\
\hline & [45] & I/R AKI & Mouse & SCID & $\mathrm{m}$ & $\mathrm{y}$ & & i.v. & $1 \times 10^{5} \mathrm{CE}$ & 1 & RNA dependent & & Increased tubular cell proliferation \\
\hline & [44] & I/R AKI & Rat & SD & $\mathrm{m}$ & $\mathrm{n}$ & & i.v. & $100 \mu g$ & 1 & $\begin{array}{l}\text { NFkB, IL-1B, MIF, PAI-1, } \\
\text { COX-2 re }\end{array}$ & $\begin{array}{l}\text { Reduced inflammatory } \\
\text { reaction reduced TNF } \alpha \\
\end{array}$ & $\begin{array}{c}\text { Reduced oxidative stress } \\
\text { Reduced mitochondrial damage }\end{array}$ \\
\hline & [47] & $\begin{array}{c}\mathrm{I} / \mathrm{R} \text { renal } \\
\text { injury }\end{array}$ & Mouse & Balb/C & n.d. & $\mathrm{n}$ & & Renal capsule & $200 \mu \mathrm{g}$ & 1 & CCR-2 & $\begin{array}{l}\text { Inhibition effect on } \\
\text { recruitment of Monocytes } \\
\text { and Macrophages }\end{array}$ & $\begin{array}{l}\text { CCR2 enriched in Evs } \rightarrow \text { binding to } \\
\text { extracellular CCL-2 }\end{array}$ \\
\hline & [39] & Renal injury & Mouse & C57BL/6 & n.d. & $\mathrm{n}$ & & i.v. & $30 \mu \mathrm{g}$ & 3 & & Lymphocyte infiltration & $\begin{array}{l}\text { Improved renal function } \\
\text { Decreased injury } \\
\text { Prevented fibrosis } \\
\end{array}$ \\
\hline & [46] & $\begin{array}{c}\text { Renal } \\
\text { allograft }\end{array}$ & Rat & Lewis & $\mathrm{m}$ & $\mathrm{n}$ & & n.d. & n.d. & 1 & & $\begin{array}{l}\text { Infiltrated lymphocytes T- } \\
\text { and B-cell count higher, NK } \\
\text { cells reduced TNF } \alpha \\
\text { transcripts reduced }\end{array}$ & no difference in kidney function \\
\hline
\end{tabular}


Table 2. Cont

\begin{tabular}{|c|c|c|c|c|c|c|c|c|c|c|c|c|c|}
\hline \multirow[t]{2}{*}{ Organ } & \multirow[t]{2}{*}{ Reference } & \multirow[t]{2}{*}{ Disease } & \multicolumn{3}{|c|}{ Animal } & \multirow[t]{2}{*}{$\begin{array}{c}\text { Xenogenic } \\
\text { Application }\end{array}$} & \multirow[t]{2}{*}{$\begin{array}{c}\text { Functional } \\
\text { Testing In Vitro }\end{array}$} & \multirow[t]{2}{*}{ Application } & \multirow[t]{2}{*}{ EV Dose } & \multirow[t]{2}{*}{$\begin{array}{c}\text { No. of } \\
\text { Injections }\end{array}$} & \multirow[t]{2}{*}{ Factors } & \multirow[t]{2}{*}{$\begin{array}{c}\text { Immunomodulatory } \\
\text { Effects }\end{array}$} & \multirow[t]{2}{*}{$\begin{array}{c}\text { Described Effects After MSC-EV } \\
\text { Application }\end{array}$} \\
\hline & & & Species & Strain & Gender & & & & & & & & \\
\hline \multirow{8}{*}{ Heart } & [29] & AMI & Rat & Wistar & $\mathrm{m}$ & $\mathrm{y}$ & & $\begin{array}{c}\text { Border zone } \\
\text { heart }\end{array}$ & $20 \mu \mathrm{L}$ & 4 & & & $\begin{array}{l}\text { Formation of new blood vessels } \\
\text { Reduced infarct size }\end{array}$ \\
\hline & [48] & AMI & Rat & SD & n.d. & $\mathrm{y}$ & Apoptosis assay & i.v. & $400 \mu \mathrm{g}$ & 1 & $\begin{array}{l}\text { AKT overexpression, } \\
\text { PDGF-D }\end{array}$ & & $\begin{array}{l}\text { Formation of new blood vessels } \\
\text { Improved cardiac function }\end{array}$ \\
\hline & [49] & AMI & Rat & SD & $\mathrm{m}$ & $\mathrm{n}$ & & Infarct border & $20 \mu \mathrm{g}$ & 1 & $\begin{array}{c}\text { miR29, miR24 } \\
\text { upregulated } \\
\text { miR34, miR130, miR378 } \\
\text { downregulated }\end{array}$ & Reduced inflammation & $\begin{array}{c}\text { No fibrosis } \\
\text { Improved cardiac function } \\
\text { Increased cell proliferation and } \\
\text { migration }\end{array}$ \\
\hline & [50] & AMI & Rat & SD & $\mathrm{m}$ & $\mathrm{n}$ & $\begin{array}{c}\text { T-cell } \\
\text { proliferation } \\
\text { Tube formation } \\
\text { EV uptake } \\
\end{array}$ & Infarct border & $80 \mu \mathrm{g}$ & 1 & & $\begin{array}{l}\text { Decreased proliferation of } \\
\text { inflammatory cells }\end{array}$ & $\begin{array}{l}\text { Formation of new blood vessels } \\
\text { Improved cardiac function }\end{array}$ \\
\hline & [51] & AMI & Rat & SD & $\mathrm{m}$ & $\mathrm{y}$ & $\begin{array}{l}\text { Tube formation } \\
\text { EV uptake }\end{array}$ & i.v. & $400 \mu \mathrm{g}$ & 1 & Bcl2 & & $\begin{array}{l}\text { Improved cardiac function } \\
\text { Reduced fibrosis } \\
\text { Increased cardiomyocyte proliferation }\end{array}$ \\
\hline & [54] & AMI & Rat & SD & $\mathrm{f}$ & $\mathrm{n}$ & & Intramyocardial & $4 \times 10^{6} \mathrm{CE}$ & 1 & miR22, miR19, PTEN & & $\begin{array}{l}\text { Improved cardiac function } \\
\text { Reduced infarct size } \\
\text { Reduced apoptosis }\end{array}$ \\
\hline & [21] & AMI & Mouse & n.d. & n.d. & $\mathrm{y}$ & & i.v. & $0.4 \mu \mathrm{g}$ & 1 & & $\begin{array}{l}\text { Independent of immune } \\
\text { cells }\end{array}$ & Reduced infarct size \\
\hline & [53] & AMI & Mouse & C57BL/6 & n.d. & $\mathrm{n}$ & & Infarct border & $1 \mu \mathrm{g}$ & 1 & miR122 & & $\begin{array}{c}\text { Reduced apoptosis } \\
\text { Reduced fibrosis } \\
\text { Improved cardiac function } \\
\end{array}$ \\
\hline \multirow{5}{*}{ Liver } & [58] & $\begin{array}{l}\text { Acute liver } \\
\text { injury }\end{array}$ & Mouse & C57BL $/ 6$ & $\mathrm{~m}$ & $\mathrm{y}$ & & i.s. & $0.4 \mu \mathrm{g}$ & 1 & $\begin{array}{c}\text { HGF, HGFR protein, } \\
\text { II6ST/gpr30, } \\
\text { TNFRSF1A/TNFR1, } \\
\text { CXCL2/MP-2 protein, } \\
\text { iNOS, NO, COX2, } \\
\text { MIP-2 } \\
\end{array}$ & & $\begin{array}{l}\text { Decreased apoptosis } \\
\text { Decreased liver injury } \\
\text { Induced hepatocyte proliferation }\end{array}$ \\
\hline & [59] & $\begin{array}{l}\text { Acute liver } \\
\text { injury }\end{array}$ & Mouse & $\mathrm{BALB} / \mathrm{c}$ & n.d. & $\mathrm{y}$ & & i.v. or oral & $\begin{array}{c}8 / 16 / 32 \\
\mathrm{mg} / \mathrm{kg} \text { BW }\end{array}$ & 1 & GPX1, Bcl2, ROS, MDA & $\begin{array}{c}\text { Reduced serum levels of } \\
\text { pro-inflammatory cytokines }\end{array}$ & $\begin{array}{c}\text { Rescued liver failure } \\
\text { Increased viability } \\
\text { Decreased oxidative stress }\end{array}$ \\
\hline & [55] & $\begin{array}{l}\text { Hepatic } \\
\text { failure }\end{array}$ & Mouse & C57BL/6 & $\mathrm{m}$ & $\mathrm{y}$ & $\begin{array}{l}\text { EV uptake } \\
\text { Apoptosis assay }\end{array}$ & i.v. & $1 \mu \mathrm{g} / \mu \mathrm{L}$ & 1 & $\begin{array}{l}\text { Caspase-3, TNF- } \alpha, \text { IL-6, } \\
\text { IL-1B }\end{array}$ & $\begin{array}{c}\text { Inhibitory } \\
\text { immunomodulation of } \\
\text { activated MNSc decreased } \\
\text { NK-cells }\end{array}$ & $\begin{array}{l}\text { Reduced apoptosis } \\
\text { Improved liver function }\end{array}$ \\
\hline & [56] & $\begin{array}{l}\text { Hepatic } \\
\text { failure }\end{array}$ & Mouse & C57BL $/ 6$ & $\mathrm{~m}$ & $\mathrm{Y}^{*}$ & & i.p./i.v. & $\begin{array}{c}2 \times 10^{8} \text { to } 2 \times \\
10^{10} \mathrm{EVs}\end{array}$ & 1 & $\begin{array}{l}\text { Y-RNA-1, MIP2, IL-6, } \\
\text { IL-1 alpha, MIP-3 beta, } \\
\text { IP-10, MCP-1, MCP-3-3 }\end{array}$ & & $\begin{array}{l}\text { No apoptosis } \\
\text { Reduced hepatic injury } \\
\text { Improved survival }\end{array}$ \\
\hline & [57] & $\begin{array}{c}\text { Hepatic I/R } \\
\text { injury }\end{array}$ & Rat & SD & $\mathrm{m}$ & $\mathrm{y}$ & & i.v. & $600 \mu \mathrm{g}$ & 1 & TNF- $\alpha$, IL-6, HMGB-1 & $\begin{array}{c}\text { Reduced inflammatory } \\
\text { markers Reduced } \\
\text { infiltration of inflammatory } \\
\text { cells }\end{array}$ & $\begin{array}{l}\text { Reduced necrosis/ apoptosis } \\
\text { Decreased liver injury } \\
\text { Decreased oxidative stress } \\
\text { Induced hepatocyte proliferation }\end{array}$ \\
\hline
\end{tabular}


Table 2. Cont.

\begin{tabular}{|c|c|c|c|c|c|c|c|c|c|c|c|c|c|}
\hline \multirow[t]{2}{*}{ Organ } & \multirow[t]{2}{*}{ Reference } & \multirow[t]{2}{*}{ Disease } & \multicolumn{3}{|c|}{ Animal } & \multirow[t]{2}{*}{$\begin{array}{c}\text { Xenogenic } \\
\text { Application }\end{array}$} & \multirow[t]{2}{*}{$\begin{array}{c}\text { Functional } \\
\text { Testing In Vitro }\end{array}$} & \multirow[t]{2}{*}{ Application } & \multirow[t]{2}{*}{ EV Dose } & \multirow[t]{2}{*}{$\begin{array}{l}\text { No. of } \\
\text { Injections }\end{array}$} & \multirow[t]{2}{*}{ Factors } & \multirow[t]{2}{*}{$\begin{array}{l}\text { Immunomodulatory } \\
\text { Effects }\end{array}$} & \multirow[t]{2}{*}{$\begin{array}{l}\text { Described Effects After MSC-EV } \\
\text { Application }\end{array}$} \\
\hline & & & Species & Strain & Gender & & & & & & & & \\
\hline \multirow{12}{*}{ Brain } & [66] & Stroke & Rat & Wistar & $\mathrm{m}$ & $n$ & & i.v. & $100 \mu g$ & 1 & & & $\begin{array}{l}\text { Improved neurological function } \\
\text { Neurovascular remodeling }\end{array}$ \\
\hline & [69] & Stroke & Rat & Wistar & $\mathrm{m}$ & $\mathrm{n}$ & & n.d. & $100 \mu \mathrm{g}$ & 1 & miR-133 & & Improved functional recovery \\
\hline & [65] & Stroke & Rat & Wistar & $\mathrm{m}$ & $\mathrm{n}$ & & i.v. & $100 \mu g$ & 1 & $\begin{array}{l}\text { miR17-92 Cluster } \\
\text { PTEN }\end{array}$ & & $\begin{array}{l}\text { Improved neurological function } \\
\text { Increased neural remodeling }\end{array}$ \\
\hline & [63] & Stroke & Mouse & C57BL/6 & $\mathrm{m}$ & $\mathrm{y}$ & & i.v. & $2 \times 10^{6} \mathrm{CE}$ & 3 & & $\begin{array}{l}\text { Reduced T-call activation } \\
\text { B-cell, NK-cell, T-cell } \\
\text { lymphopenia } \\
\end{array}$ & $\begin{array}{l}\text { Long-term neuroprotection } \\
\text { Increased angioneogenesis }\end{array}$ \\
\hline & [64] & Stroke & Rat & n.d. & $\mathrm{m}$ & $\mathrm{y}$ & & i.v. & $100 \mu \mathrm{g}$ & 1 & $\begin{array}{c}\text { MMP-9, IL-1B, TNF } \alpha, \\
\text { RANTSS, PAI-1, NF-KB, } \\
\text { iNOS, NOX-1, NOX-2, } \\
\text { c-Casp3, c-PARP } \\
\text { p-SMMAD, TGF-B, } \\
\text { SMAD1/5, BMP-2 }\end{array}$ & $\begin{array}{l}\text { Reduced infiltration of } \\
\text { CD11+ and CD } 68+\text { cells }\end{array}$ & $\begin{array}{l}\text { Decreased oxidative stress } \\
\text { Increased angiogenesis }\end{array}$ \\
\hline & [62] & TBI & Rat & Wistar & $\mathrm{m}$ & $\mathrm{y}$ & & i.v. & $100 \mu \mathrm{g}$ & 1 & & $\begin{array}{c}\text { Reduced } \\
\text { neuroinflammation reduced } \\
\text { CD68+ cells at infarct zone }\end{array}$ & $\begin{array}{l}\text { Improved functional recovery } \\
\text { Increased cell proliferation } \\
\text { Reduced neuroinflammation }\end{array}$ \\
\hline & [68] & TBI & Rat & Wistar & $\mathrm{m}$ & $\mathrm{n}$ & & i.v. & $100 \mu \mathrm{g}$ & 1 & & $\begin{array}{c}\text { Reduced } \\
\text { neuroiflammation reduced } \\
\text { CD68+ cells at infarct zone }\end{array}$ & $\begin{array}{l}\text { Improved functional recovery } \\
\text { Increased cell proliferation } \\
\text { Reduced neuroinflammation }\end{array}$ \\
\hline & [61] & TBI & Mouse & $\mathrm{C} 57 \mathrm{BL} / 6$ & $\mathrm{~m}$ & $\mathrm{y}$ & & i.v. & $30 \mu \mathrm{g}$ & 1 & & $\begin{array}{c}\text { Suppressing } \\
\text { Neuroinflammation }\end{array}$ & Rescue cognitive impairments \\
\hline & [73] & Brain injury & Rat & Wistar & n.d. & $\mathrm{y}$ & & i.p. & $\begin{array}{c}1 \times 10^{8} \mathrm{CE} / \mathrm{kg} \\
\mathrm{BW}\end{array}$ & 1 & & $\begin{array}{l}\text { Modulated inflammatory } \\
\text { responses }\end{array}$ & $\begin{array}{l}\text { Improved cognitive function } \\
\text { Reduced cellular degeneration }\end{array}$ \\
\hline & [72] & $\begin{array}{c}\text { Preterm } \\
\text { brain injury }\end{array}$ & Sheep & Texel & n.d. & $\mathrm{y}$ & & i.v. & $2 \times 10^{7} \mathrm{CE}$ & 2 & IBA-1 & Increased immunoreactivity & $\begin{array}{l}\text { Decreased structural injury } \\
\text { Functional neuroprotective effects } \\
\text { Improved function }\end{array}$ \\
\hline & [70] & $\begin{array}{l}\text { Cerebral } \\
\text { apoplexy }\end{array}$ & Rat & n.d. & n.d. & $\mathrm{y}$ & & i.v. & $2.4 \times 10^{4} \mathrm{EVs}$ & 3 & & $\begin{array}{c}\text { Reduced quantity of B-cells, } \\
\text { NK cells, and T-cells all } \\
\text { increased; } \\
\text { neuroinflammation (fewer } \\
\text { CD68+ cells in infarct zone) } \\
\text { attenuated } \\
\text { immunosuppression } \\
\text { (reduced numbers of } \\
\text { activated T-cells) }\end{array}$ & $\begin{array}{l}\text { Identical effect of MSCs and MSC-EVs } \\
\text { Increased neuron survival }\end{array}$ \\
\hline & [71] & SCI & Rat & SD & male & $\mathrm{n}$ & & i.v. & $100 \mu \mathrm{g}$ & 1 & $\begin{array}{l}\text { OPC } \\
\text { A2B5 } \\
\text { CNP-ase }\end{array}$ & & $\begin{array}{l}\text { Improved functional recovery } \\
\text { Increased angiogenesis }\end{array}$ \\
\hline
\end{tabular}

AKI, acute kidney injury; I/R, ischemia/reperfusion; AMI, acute myocardial injury; TBI, traumatic brain injury; SIC, subcortical ischemic stroke; n.d., not defined; SD, Sprague Dawley;

SCID, severe combined immunodeficiency; f, female; $m$, male; $y$, yes; $n$, no; EV, extracellular vesicles; i.v., intravenously; i.a., intraabdominal; i.p., intraperitoneal; i.s., intrasplenic; $\mu \mathrm{g}$, microgram; $\mathrm{CE}$, cell equivalent; $\mathrm{ml}$, milliliter; $\mathrm{MV}$, microvesicle; $\mathrm{CD}$, cluster of differentiation; IL, Interleukin. 
Acknowledgments: For the collaboration and general support, we would like to thank our colleagues from the institute, as well as all collaboration partners. For the proof reading, we thank our group members Sandra Viale Bouroncle and Simon Staubach. For the financial support of our EV research, we are grateful to the Medical Faculty of the University of Duisburg-Essen (IFORES), the Volkswagen Foundation, the Stem Cell Network North Rhine Westphalia and the LeitmarktAgentur.NRW and European Union (European Regional Development Fund 2014-2020), as well as to the European Union for the EU program ME-HaD (COST Action BM1202).

Author Contributions: Verena Börger and Michel Bremer designed the concept and organized the writing of the manuscript. All authors provided information and participated in writing and proofreading. The final version of the manuscript was edited by Verena Börger and Bernd Giebel.

Conflicts of Interest: The authors declare no conflict of interest.

\section{References}

1. Friedenstein, A.J.; Deriglasova, U.F.; Kulagina, N.N.; Panasuk, A.F.; Rudakowa, S.F.; Luria, E.A.; Ruadkow, I.A. Precursors for fibroblasts in different populations of hematopoietic cells as detected by the in vitro colony assay method. Exp. Hematol. 1974, 2, 83-92. [PubMed]

2. Pittenger, F.M.; Mackay, A.M.; Beck, S.C.; Jaiswal, R.K.; Douglas, R.; Mosca, J.D.; Moorman, M.A.; Simonetti, D.W.; Craig, S.; Marshak, D.R. Multilineage potential of adult human mesenchymal stem cells. Science 1999, 284, 143-147. [CrossRef] [PubMed]

3. Dominici, M.; le Blanc, K.; Mueller, I.; Slaper-Cortenbach, I.; Marini, F.; Krause, D.; Deans, R.; Keating, A.; Prockop, D.; Horwitz, E. Minimal criteria for defining multipotent mesenchymal stromal cells. The international society for cellular therapy position statement. Cytotherapy 2006, 8, 315-317. [CrossRef] [PubMed]

4. Ryan, J.M.; Barry, F.P.; Murphy, J.M.; Mahon, B.P. Mesenchymal stem cells avoid allogeneic rejection. J. Inflamm. 2005, 2, 8. [CrossRef] [PubMed]

5. Le Blanc, K.; Tammik, L.; Sundberg, B.; Haynesworth, S.E.; Ringden, O. Mesenchymal stem cells inhibit and stimulate mixed lymphocyte cultures and mitogenic responses independently of the major histocompatibility complex. Scand. J. Immunol. 2003, 57, 11-20. [CrossRef] [PubMed]

6. Le Blanc, K.; Ringden, O. Immunobiology of human mesenchymal stem cells and future use in hematopoietic stem cell transplantation. Biol. Blood Marrow Transplant. 2005, 11, 321-334. [CrossRef] [PubMed]

7. Di Nicola, M.; Carlo-Stella, C.; Magni, M.; Milanesi, M.; Longoni, P.D.; Matteucci, P.; Grisanti, S.; Gianni, A.M. Human bone marrow stromal cells suppress t-lymphocyte proliferation induced by cellular or nonspecific mitogenic stimuli. Blood 2002, 99, 3838-3843. [CrossRef] [PubMed]

8. Bartholomew, A.; Sturgeon, C.; Siatskas, M.; Ferrer, K.; McIntosh, K.; Patil, S.; Hardy, W.; Devine, S.; Ucker, D.; Deans, R.; et al. Mesenchymal stem cells suppress lymphocyte proliferation in vitro and prolong skin graft survival in vivo. Exp. Hematol. 2002, 30, 42-48. [CrossRef]

9. Heldring, N.; Mager, I.; Wood, M.J.; le Blanc, K.; Andaloussi, S.E. Therapeutic potential of multipotent mesenchymal stromal cells and their extracellular vesicles. Hum. Gene Ther. 2015, 26, 506-517. [CrossRef] [PubMed]

10. Lee, R.H.; Pulin, A.A.; Seo, M.J.; Kota, D.J.; Ylostalo, J.; Larson, B.L.; Semprun-Prieto, L.; Delafontaine, P.; Prockop, D.J. Intravenous hmscs improve myocardial infarction in mice because cells embolized in lung are activated to secrete the anti-inflammatory protein Tsg-6. Cell Stem Cell 2009, 5, 54-63. [CrossRef] [PubMed]

11. Caplan, A.I.; Correa, D. The Msc: An Injury Drugstore. Cell Stem Cell 2011, 9, 11-15. [CrossRef] [PubMed]

12. Gnecchi, M.; He, H.; Liang, O.D.; Melo, L.G.; Morello, F.; Mu, H.; Noiseux, N.; Zhang, L.; Pratt, R.E.; Ingwall, J.S.; et al. Paracrine action accounts for marked protection of ischemic heart by akt-modified mesenchymal stem cells. Nat. Med. 2005, 11,367-368. [CrossRef] [PubMed]

13. Gnecchi, M.; He, H.; Noiseux, N.; Liang, O.D.; Zhang, L.; Morello, F.; Mu, H.; Melo, L.G.; Pratt, R.E.; Ingwall, J.S.; et al. Evidence supporting paracrine hypothesis for akt-modified mesenchymal stem cell-mediated cardiac protection and functional improvement. FASEB J. 2006, 20, 661-669. [CrossRef] [PubMed]

14. Timmers, L.; Lim, S.K.; Arslan, F.; Armstrong, J.S.; Hoefer, I.E.; Doevendans, P.A.; Piek, J.J.; el Oakley, R.M.; Choo, A.; Lee, C.N.; et al. Reduction of myocardial infarct size by human mesenchymal stem cell conditioned medium. Stem Cell Res. 2007, 1, 129-137. [CrossRef] [PubMed] 
15. Togel, F.; Hu, Z.; Weiss, K.; Isaac, J.; Lange, C.; Westenfelder, C. Administered mesenchymal stem cells protect against ischemic acute renal failure through differentiation-independent mechanisms. Am. J. Physiol. Renal Physiol. 2005, 289, F31-F42. [CrossRef] [PubMed]

16. Togel, F.; Weiss, K.; Yang, Y.; Hu, Z.; Zhang, P.; Vasculotropic, C.W. Paracrine actions of infused mesenchymal stem cells are important to the recovery from acute kidney injury. Am. J. Physiol. Renal Physiol. 2007, 292, F1626-F1635. [CrossRef] [PubMed]

17. Reis, L.A.; Borges, F.T.; Simoes, M.J.; Borges, A.A.; Sinigaglia-Coimbra, R.; Schor, N. Bone marrow-derived mesenchymal stem cells repaired but did not prevent gentamicin-induced acute kidney injury through paracrine effects in rats. PLOS ONE 2012, 7, e44092. [CrossRef] [PubMed]

18. Lee, C.; Mitsialis, S.A.; Aslam, M.; Vitali, S.H.; Vergadi, E.; Konstantinou, G.; Sdrimas, K.; Fernandez-Gonzalez, A.; Kourembanas, S. Exosomes mediate the cytoprotective action of mesenchymal stromal cells on hypoxia-induced pulmonary hypertension. Circulation 2012, 126, 2601-3611. [CrossRef] [PubMed]

19. Zanotti, L.; Sarukhan, A.; Dander, E.; Castor, M.; Cibella, J.; Soldani, C.; Trovato, A.E.; Ploia, C.; Luca, G.; Calvitti, M.; et al. Encapsulated mesenchymal stem cells for in vivo immunomodulation. Leukemia 2013, 27, 500-503. [CrossRef] [PubMed]

20. Bruno, S.; Grange, C.; Deregibus, M.C.; Calogero, R.A.; Saviozzi, S.; Collino, F.; Morando, L.; Busca, A.; Falda, M.; Bussolati, B.; et al. Mesenchymal stem cell-derived microvesicles protect against acute tubular injury. J. Am. Soc. Nephrol. 2009, 20, 1053-1067. [CrossRef] [PubMed]

21. Lai, R.C.; Arslan, F.; Lee, M.M.; Sze, N.S.; Choo, A.; Chen, T.S.; Salto-Tellez, M.; Timmers, L.; Lee, C.N.; el Oakley, R.M.; et al. Exosome secreted by msc reduces myocardial ischemia/reperfusion injury. Stem Cell Res. 2010, 4, 214-222. [CrossRef] [PubMed]

22. Gould, S.J.; Raposo, G. As We wait: Coping with an imperfect nomenclature for extracellular vesicles. J. Extracell. Vesicles 2013, 2. [CrossRef] [PubMed]

23. Raposo, G.; Stoorvogel, W. Extracellular vesicles: Exosomes, microvesicles, and friends. J. Cell Biol. 2013, 200, 373-383. [CrossRef] [PubMed]

24. Johnstone, R.M.; Adam, M.; Hammond, J.R.; Orr, L.; Turbide, C. Vesicle formation during reticulocyte maturation. association of plasma membrane activities with released vesicles (exosomes). J. Biol. Chem. 1987, 262, 9412-9420. [PubMed]

25. Giebel, B.; Wodarz, A. Tumor suppressors: Control of signaling by endocytosis. Curr. Biol. 2006, 16, R91-R92. [CrossRef] [PubMed]

26. Sokolova, V.; Ludwig, A.K.; Hornung, S.; Rotan, O.; Horn, P.A.; Epple, M.; Giebel, B. Characterisation of exosomes derived from human cells by nanoparticle tracking analysis and scanning electron microscopy. Colloids Surf. B Biointerfaces 2011, 87, 146-150. [CrossRef] [PubMed]

27. Thery, C.; Amigorena, S.; Raposo, G.; Clayton, A. Isolation and characterization of exosomes from cell culture supernatants and biological fluids. Curr. Protoc. Cell Biol. 2006, 3, 22. [CrossRef] [PubMed]

28. Kim, D.K.; Lee, J.; Kim, S.R.; Choi, D.S.; Yoon, Y.J.; Kim, J.H.; Go, G.; Nhung, D.; Hong, K.; Jang, S.C.; et al. Evpedia: A community web portal for extracellular vesicles research. Bioinformatics 2015, 31, 933-939. [CrossRef] [PubMed]

29. Bian, S.; Zhang, L.; Duan, L.; Wang, X.; Min, Y.; Yu, H. Extracellular vesicles derived from human bone marrow mesenchymal stem cells promote angiogenesis in a rat myocardial infarction model. J. Mol. Med. Berl. 2014, 92, 387-397. [CrossRef] [PubMed]

30. Lotvall, J.; Hill, A.F.; Hochberg, F.; Buzas, E.I.; di Vizio, D.; Gardiner, C.; Gho, Y.S.; Kurochkin, I.V.; Mathivanan, S.; Quesenberry, P.; et al. Minimal experimental requirements for definition of extracellular vesicles and their functions: A position statement from the international society for extracellular vesicles. J. Extracell. Vesicles 2014, 3, 26913. [CrossRef] [PubMed]

31. Raposo, G.; Nijman, H.W.; Stoorvogel, W.; Liejendekker, R.; Harding, C.V.; Melief, C.J.; Geuze, H.J. B lymphocytes secrete antigen-presenting vesicles. J. Exp. Med. 1996, 183, 1161-1172. [CrossRef] [PubMed]

32. Ludwig, A.K.; Giebel, B. Exosomes: Small vesicles participating in intercellular communication. Int. J. Biochem. Cell Biol. 2012, 44, 11-15. [CrossRef] [PubMed]

33. Yanez-Mo, M.; Siljander, P.R.; Andreu, Z.; Zavec, A.B.; Borras, F.E.; Buzas, E.I.; Buzas, K.; Casal, E.; Cappello, F.; Carvalho, J.; et al. Biological properties of extracellular vesicles and their physiological functions. J. Extracell. Vesicles 2015, 4, 27066. [CrossRef] [PubMed] 
34. Zitvogel, L.; Regnault, A.; Lozier, A.; Wolfers, J.; Flament, C.; Tenza, D.; Ricciardi-Castagnoli, P.; Raposo, G.; Amigorena, S. Eradication of established murine tumors using a novel cell-free vaccine: Dendritic cell-derived exosomes. Nat. Med. 1998, 4, 594-600. [CrossRef] [PubMed]

35. Fais, S.; O’Driscoll, L.; Borras, F.E.; Buzas, E.; Camussi, G.; Cappello, F.; Carvalho, J.; da Silva, A.C.; del Portillo, H.; el Andaloussi, S.; et al. Evidence-based clinical use of nanoscale extracellular vesicles in nanomedicine. ACS Nano 2016, 10, 3886-3899. [CrossRef] [PubMed]

36. Valadi, H.; Ekstrom, K.; Bossios, A.; Sjostrand, M.; Lee, J.J.; Lotvall, J.O. Exosome-mediated transfer of mrnas and micrornas is a novel mechanism of genetic exchange between cells. Nat. Cell Biol. 2007, 9, 654-659. [CrossRef] [PubMed]

37. Deregibus, M.C.; Cantaluppi, V.; Calogero, R.; Iacono, M.L.; Tetta, C.; Biancone, L.; Bruno, S.; Bussolati, B.; Camussi, G. Endothelial progenitor cell derived microvesicles activate an angiogenic program in endothelial cells by a horizontal transfer of mrna. Blood 2007, 110, 2440-2448. [CrossRef] [PubMed]

38. Ratajczak, J.; Miekus, K.; Kucia, M.; Zhang, J.; Reca, R.; Dvorak, P.; Ratajczak, M.Z. Embryonic stem cell-derived microvesicles reprogram hematopoietic progenitors: Evidence for horizontal transfer of mrna and protein delivery. Leukemia 2006, 20, 847-856. [CrossRef] [PubMed]

39. He, J.; Wang, Y.; Sun, S.; Yu, M.; Wang, C.; Pei, X.; Zhu, B.; Wu, J.; Zhao, W. Bone marrow stem cells-derived microvesicles protect against renal injury in the mouse remnant kidney model. Nephrol. Carlton 2012, 17, 493-500. [CrossRef] [PubMed]

40. Bruno, S.; Grange, C.; Collino, F.; Deregibus, M.C.; Cantaluppi, V.; Biancone, L.; Tetta, C.; Camussi, G. Microvesicles derived from mesenchymal stem cells enhance survival in a lethal model of acute kidney injury. PLOS ONE 2012, 7, e33115. [CrossRef] [PubMed]

41. Zhou, Y.; Xu, H.; Xu, W.; Wang, B.; Wu, H.; Tao, Y.; Zhang, B.; Wang, M.; Mao, F.; Yan, Y.; et al. Exosomes released by human umbilical cord mesenchymal stem cells protect against cisplatin-induced renal oxidative stress and apoptosis in vivo and in vitro. Stem Cell Res. Ther. 2013, 4, 34. [CrossRef] [PubMed]

42. Zou, X.; Gu, D.; Xing, X.; Cheng, Z.; Gong, D.; Zhang, G.; Zhu, Y. Human mesenchymal stromal cell-derived extracellular vesicles alleviate renal ischemic reperfusion injury and enhance angiogenesis in rats. Am. J. Transl. Res. 2016, 8, 4289-4299. [PubMed]

43. Zou, X.; Zhang, G.; Cheng, Z.; Yin, D.; Du, T.; Ju, G.; Miao, S.; Liu, G.; Lu, M.; Zhu, Y. Microvesicles derived from human wharton's jelly mesenchymal stromal cells ameliorate renal ischemia-reperfusion injury in rats by suppressing CX3CL1. Stem Cell Res. Ther. 2014, 5, 40. [CrossRef] [PubMed]

44. Lin, K.C.; Yip, H.K.; Shao, P.L.; Wu, S.C.; Chen, K.H.; Chen, Y.T.; Yang, C.C.; Sun, C.K.; Kao, G.S.; Chen, S.Y.; et al. Combination of adipose-derived mesenchymal stem cells (ADMSC) and ADMSC-derived exosomes for protecting kidney from acute ischemia-reperfusion injury. Int. J. Cardiol. 2016, 216, 173-185. [CrossRef] [PubMed]

45. Ranghino, A.; Bruno, S.; Bussolati, B.; Moggio, A.; Dimuccio, V.; Tapparo, M.; Biancone, L.; Gontero, P.; Frea, B.; Camussi, G. The effects of glomerular and tubular renal progenitors and derived extracellular vesicles on recovery from acute kidney injury. Stem Cell Res. Ther. 2017, 8, 24. [CrossRef] [PubMed]

46. Koch, M.; Lemke, A.; Lange, C. Extracellular vesicles from msc modulate the immune response to renal allografts in a mhc disparate rat Model. Stem Cells Int. 2015, 2015, 486141. [CrossRef] [PubMed]

47. Shen, B.; Liu, J.; Zhang, F.; Wang, Y.; Qin, Y.; Zhou, Z.; Qiu, J.; Fan, Y. CCR2 positive exosome released by mesenchymal stem cells suppresses macrophage functions and alleviates ischemia/reperfusion-induced renal injury. Stem Cells Int. 2016, 2016, 1240301. [CrossRef] [PubMed]

48. Ma, J.; Zhao, Y.; Sun, L.; Sun, X.; Zhao, X.; Sun, X.; Qian, H.; Xu, W.; Zhu, W. Exosomes derived from Akt-modified human umbilical cord mesenchymal stem cells improve cardiac regeneration and promote angiogenesis via activating platelet-derived growth factor D. Stem Cells Transl. Med. 2016, 6, 51-59. [CrossRef] [PubMed]

49. Shao, L.; Zhang, Y.; Lan, B.; Wang, J.; Zhang, Z.; Zhang, L.; Xiao, P.; Meng, Q.; Geng, Y.J.; Yu, X.Y.; et al. Mirna-sequence indicates that mesenchymal stem cells and exosomes have similar mechanism to enhance cardiac repair. BioMed Res. Int. 2017, 2017, 4150705. [CrossRef] [PubMed]

50. Teng, X.; Chen, L.; Chen, W.; Yang, J.; Yang, Z.; Shen, Z. Mesenchymal stem cell-derived exosomes improve the microenvironment of infarcted myocardium contributing to angiogenesis and anti-inflammation. Cell. Physiol. Biochem. 2015, 37, 2415-2424. [CrossRef] [PubMed] 
51. Zhao, Y.; Sun, X.; Cao, W.; Ma, J.; Sun, L.; Qian, H.; Zhu, W.; Xu, W. Exosomes derived from human umbilical cord mesenchymal stem cells relieve acute myocardial ischemic injury. Stem Cells Int. 2015, 2015, 761643. [CrossRef] [PubMed]

52. Yu, B.; Shao, H.; Su, C.; Jiang, Y.; Chen, X.; Bai, L.; Zhang, Y.; Li, Q.; Zhang, X.; Li, X. Exosomes derived from mscs ameliorate retinal laser injury partially by inhibition of Mcp-1. Sci. Rep. 2016, 6, 34562. [CrossRef] [PubMed]

53. Feng, Y.; Huang, W.; Wani, M.; Yu, X.; Ashraf, M. Ischemic preconditioning potentiates the protective effect of stem cells through secretion of exosomes by targeting Mecp2 via miR-22. PLoS ONE 2014, 9, e88685. [CrossRef] [PubMed]

54. Yu, B.; Kim, H.W.; Gong, M.; Wang, J.; Millard, R.W.; Wang, Y.; Ashraf, M.; Xu, M. Exosomes secreted from gata-4 overexpressing mesenchymal stem cells serve as a reservoir of anti-apoptotic micrornas for cardioprotection. Int. J. Cardiol. 2015, 182, 349-360. [CrossRef] [PubMed]

55. Chen, L.; Xiang, B.; Wang, X.; Xiang, C. Exosomes derived from human menstrual blood-derived stem cells alleviate fulminant hepatic failure. Stem Cell Res. Ther. 2017, 8, 9. [CrossRef] [PubMed]

56. Haga, H.; Yan, I.K.; Takahashi, K.; Matsuda, A.; Patel, T. Extracellular vesicles from bone marrow-derived mesenchymal stem cells improve survival from lethal hepatic failure in mice. Stem Cells Transl. Med. 2017. [CrossRef] [PubMed]

57. Nong, K.; Wang, W.; Niu, X.; Hu, B.; Ma, C.; Bai, Y.; Wu, B.; Wang, Y.; Ai, K. Hepatoprotective effect of exosomes from human-induced pluripotent stem cell-derived mesenchymal stromal cells against hepatic ischemia-reperfusion injury in rats. Cytotherapy 2016, 18, 1548-1559. [CrossRef] [PubMed]

58. Tan, C.Y.; Lai, R.C.; Wong, W.; Dan, Y.Y.; Lim, S.K.; Ho, H.K. Mesenchymal stem cell-derived exosomes promote hepatic regeneration in drug-induced liver injury models. Stem Cell Res. Ther. 2014, 5, 76. [CrossRef] [PubMed]

59. Yan, Y.; Jiang, W.; Tan, Y.; Zou, S.; Zhang, H.; Mao, F.; Gong, A.; Qian, H.; Xu, W. Hucmsc exosome-derived gpx1 is required for the recovery of hepatic oxidant injury. Mol. Ther. 2017, 25, 465-479. [CrossRef] [PubMed]

60. Li, T.; Yan, Y.; Wang, B.; Qian, H.; Zhang, X.; Shen, L.; Wang, M.; Zhou, Y.; Zhu, W.; Li, W.; et al. Exosomes derived from human umbilical cord mesenchymal stem cells alleviate liver fibrosis. Stem Cells Dev. 2013, 22, 845-854. [CrossRef] [PubMed]

61. Kim, D.K.; Nishida, H.; An, S.Y.; Shetty, A.K.; Bartosh, T.J.; Prockop, D.J. Chromatographically isolated $\mathrm{CD}^{+} 3^{+} \mathrm{CD} 81^{+}$extracellular vesicles from mesenchymal stromal cells rescue cognitive impairments after TBI. Proc. Natl. Acad. Sci. USA 2016, 113, 170-175. [CrossRef] [PubMed]

62. Zhang, Y.; Chopp, M.; Zhang, Z.G.; Katakowski, M.; Xin, H.; Qu, C.; Ali, M.; Mahmood, A.; Xiong, Y. Systemic administration of cell-free exosomes generated by human bone marrow derived mesenchymal stem cells cultured under 2D and 3D conditions improves functional recovery in rats after traumatic brain injury. Neurochem. Int. 2016. [CrossRef] [PubMed]

63. Doeppner, T.R.; Herz, J.; Gorgens, A.; Schlechter, J.; Ludwig, A.K.; Radtke, S.; de Miroschedji, K.; Horn, P.A.; Giebel, B.; Hermann, D.M. Extracellular vesicles improve post-stroke neuroregeneration and prevent postischemic immunosuppression. Stem Cells Transl. Med. 2015, 4, 1131-1143. [CrossRef] [PubMed]

64. Chen, K.H.; Chen, C.H.; Wallace, C.G.; Yuen, C.M.; Kao, G.S.; Chen, Y.L.; Shao, P.L.; Chen, Y.L.; Chai, H.T.; Lin, K.C.; et al. Intravenous Administration of xenogenic adipose-derived mesenchymal stem cells (ADMSC) and admsc-derived exosomes markedly reduced brain infarct volume and preserved neurological function in rat after acute ischemic stroke. Oncotarget 2016, 7, 74537-74556. [CrossRef] [PubMed]

65. Xin, H.; Katakowski, M.; Wang, F.; Qian, J.Y.; Liu, X.S.; Ali, M.M.; Buller, B.; Zhang, Z.G.; Chopp, M. Microrna cluster miR-17-92 cluster in exosomes enhance neuroplasticity and functional recovery after stroke in rats. Stroke 2017, 48, 747-753. [CrossRef] [PubMed]

66. Xin, H.; Li, Y.; Cui, Y.; Yang, J.J.; Zhang, Z.G.; Chopp, M. Systemic administration of exosomes released from mesenchymal stromal cells promote functional recovery and neurovascular plasticity after stroke in rats. J. Cereb. Blood Flow Metab. 2013, 33, 1711-1715. [CrossRef] [PubMed]

67. Xin, H.; Li, Y.; Liu, Z.; Wang, X.; Shang, X.; Cui, Y.; Zhang, Z.G.; Chopp, M. miR-133b promotes neural plasticity and functional recovery after treatment of stroke with multipotent mesenchymal stromal cells in rats via transfer of exosome-enriched extracellular particles. Stem Cells 2013, 31, 2737-2746. [CrossRef] [PubMed] 
68. Zhang, Y.; Chopp, M.; Meng, Y.; Katakowski, M.; Xin, H.; Mahmood, A.; Xiong, Y. Effect of exosomes derived from multipluripotent mesenchymal stromal cells on functional recovery and neurovascular plasticity in rats after traumatic brain injury. J. Neurosurg. 2015, 122, 856-867. [CrossRef] [PubMed]

69. Xin, H.; Wang, F.; Li, Y.; Lu, Q.E.; Cheung, W.L.; Zhang, Y.; Zhang, Z.G.; Chopp, M. Secondary release of exosomes from astrocytes contributes to the increase in neural plasticity and improvement of functional recovery after stroke in rats treated with exosomes harvested from microrna 133b-overexpressing multipotent mesenchymal stromal cells. Cell Transplant. 2017, 26, 243-257. [PubMed]

70. Hu, B.; Chen, S.; Zou, M.; He, Z.; Shao, S.; Liu, B. Effect of extracellular vesicles on neural functional recovery and immunologic suppression after rat cerebral apoplexy. Cell. Physiol. Biochem. 2016, 40, 155-162. [CrossRef] [PubMed]

71. Otero-Ortega, L.; Laso-Garcia, F.; Frutos, M.D.G.; Rodriguez-Frutos, B.; Pascual-Guerra, J.; Fuentes, B.; Diez-Tejedor, E.; Gutierrez-Fernandez, M. White matter repair after extracellular vesicles administration in an experimental animal model of subcortical stroke. Sci. Rep. 2017, 7, 44433. [CrossRef] [PubMed]

72. Ophelders, D.R.; Wolfs, T.G.; Jellema, R.K.; Zwanenburg, A.; Andriessen, P.; Delhaas, T.; Ludwig, A.K.; Radtke, S.; Peters, V.; Janssen, L.; et al. Mesenchymal stromal cell-derived extracellular vesicles protect the fetal brain after hypoxia-ischemia. Stem Cells Transl. Med. 2016, 5, 754-763. [CrossRef] [PubMed]

73. Drommelschmidt, K.; Serdar, M.; Bendix, I.; Herz, J.; Bertling, F.; Prager, S.; Keller, M.; Ludwig, A.K.; Duhan, V.; Radtke, S.; et al. Mesenchymal stem cell-derived extracellular vesicles ameliorate inflammation-induced preterm brain injury. Brain Behav. Immun. 2017, 60, 220-232. [CrossRef] [PubMed]

74. Cheng, Q.; Zhang, Z.; Zhang, S.; Yang, H.; Zhang, X.; Pan, J.; Weng, L.; Sha, D.; Zhu, M.; Hu, X.; et al. Human umbilical cord mesenchymal stem cells protect against ischemic brain injury in mouse by regulating peripheral immunoinflammation. Brain. Res. 2015, 1594, 293-304. [CrossRef] [PubMed]

75. Kordelas, L.; Rebmann, V.; Ludwig, A.K.; Radtke, S.; Ruesing, J.; Doeppner, T.R.; Epple, M.; Horn, P.A.; Beelen, D.W.; Giebel, B. MSC-derived exosomes: A novel tool to treat therapy-refractory graft-versus-host disease. Leukemia 2014, 28, 970-973. [CrossRef] [PubMed]

76. Nassar, W.; El-Ansary, M.; Sabry, D.; Mostafa, M.A.; Fayad, T.; Kotb, E.; Temraz, M.; Saad, A.N.; Essa, W.; Adel, H. Umbilical cord mesenchymal stem cells derived extracellular vesicles can safely ameliorate the progression of chronic kidney diseases. Biomater. Res. 2016, 20, 21. [CrossRef] [PubMed]

77. Lener, T.; Gimona, M.; Aigner, L.; Borger, V.; Buzas, E.; Camussi, G.; Chaput, N.; Chatterjee, D.; Court, F.A.; del Portillo, H.A.; et al. Applying extracellular vesicles based therapeutics in clinical trials-An ISEV position paper. J. Extracell. Vesicles 2015, 4, 30087. [CrossRef] [PubMed]

78. Zhang, B.; Yin, Y.; Lai, R.C.; Tan, S.S.; Choo, A.B.; Lim, S.K. Mesenchymal stem cell secretes immunologically active exosomes. Stem Cells Dev. 2014, 23, 1233-1244. [CrossRef] [PubMed]

79. Kilpinen, L.; Impola, U.; Sankkila, L.; Ritamo, I.; Aatonen, M.; Kilpinen, S.; Tuimala, J.; Valmu, L.; Levijoki, J.; Finckenberg, P.; et al. Extracellular membrane vesicles from umbilical cord blood-derived MSC protect against ischemic acute kidney injury, a feature that is lost after inflammatory conditioning. J. Extracell. Vesicles 2013, 2. [CrossRef] [PubMed]

80. Sun, L.; Xu, R.; Sun, X.; Duan, Y.; Han, Y.; Zhao, Y.; Qian, H.; Zhu, W.; Xu, W. Safety evaluation of exosomes derived from human umbilical cord mesenchymal stromal cell. Cytotherapy 2016, 18, 413-422. [CrossRef] [PubMed]

81. Arslan, F.; Lai, R.C.; Smeets, M.B.; Akeroyd, L.; Choo, A.; Aguor, E.N.; Timmers, L.; van Rijen, H.V.; Doevendans, P.A.; Pasterkamp, G.; et al. Mesenchymal stem cell-derived exosomes increase ATP levels, decrease oxidative stress and activate PI3K/AKT pathway to enhance myocardial viability and prevent adverse remodeling after myocardial ischemia/reperfusion injury. Stem Cell Res. 2013, 10, 301-312. [CrossRef] [PubMed]

82. Wang, L.; Gu, Z.; Zhao, X.; Yang, N.; Wang, F.; Deng, A.; Zhao, S.; Luo, L.; Wei, H.; Guan, L.; et al. Extracellular vesicles released from human umbilical cord-derived mesenchymal stromal cells prevent life-threatening acute graft-versus-host disease in a mouse model of allogeneic hematopoietic stem cell transplantation. Stem Cells Dev. 2016, 25, 1874-1883. [CrossRef] [PubMed]

83. Rager, T.M.; Olson, J.K.; Zhou, Y.; Wang, Y.; Besner, G.E. Exosomes secreted from bone marrow-derived mesenchymal stem cells protect the intestines from experimental necrotizing enterocolitis. J. Pediatr. Surg. 2016, 51, 942-947. [CrossRef] [PubMed] 
84. Nagaishi, K.; Mizue, Y.; Chikenji, T.; Otani, M.; Nakano, M.; Konari, N.; Fujimiya, M. Mesenchymal stem cell therapy ameliorates diabetic nephropathy via the paracrine effect of renal trophic factors including exosomes. Sci. Rep. 2016, 6, 34842. [CrossRef] [PubMed]

85. Wen, S.; Dooner, M.; Cheng, Y.; Papa, E.; del Tatto, M.; Pereira, M.; Deng, Y.; Goldberg, L.; Aliotta, J.; Chatterjee, D.; et al. Mesenchymal stromal cell-derived extracellular vesicles rescue radiation damage to murine marrow hematopoietic cells. Leukemia 2016, 30, 2221-2231. [CrossRef] [PubMed]

86. Zhang, B.; Wang, M.; Gong, A.; Zhang, X.; Wu, X.; Zhu, Y.; Shi, H.; Wu, L.; Zhu, W.; Qian, H.; et al. Hucmsc-exosome mediated-Wnt4 signaling is required for cutaneous wound healing. Stem Cells 2015, 33, 2158-2168. [CrossRef] [PubMed]

87. Ti, D.; Hao, H.; Tong, C.; Liu, J.; Dong, L.; Zheng, J.; Zhao, Y.; Liu, H.; Fu, X.; Han, W. LPS-preconditioned mesenchymal stromal cells modify macrophage polarization for resolution of chronic inflammation via exosome-shuttled let-7b. J. Transl. Med. 2015, 13, 308. [CrossRef] [PubMed]

88. Zhu, Y.G.; Feng, X.M.; Abbott, J.; Fang, X.H.; Hao, Q.; Monsel, A.; Qu, J.M.; Matthay, M.A.; Lee, J.W. Human Mesenchymal stem cell microvesicles for treatment of escherichia coli endotoxin-induced acute lung injury in mice. Stem Cells 2014, 32, 116-125. [CrossRef] [PubMed]

89. Monsel, A.; Zhu, Y.G.; Gennai, S.; Hao, Q.; Hu, S.; Rouby, J.J.; Rosenzwajg, M.; Matthay, M.A.; Lee, J.W. Therapeutic effects of human mesenchymal stem cell-derived microvesicles in severe pneumonia in mice. Am. J. Respir. Crit. Care Med. 2015, 192, 324-336. [CrossRef] [PubMed]

90. Cruz, F.F.; Borg, Z.D.; Goodwin, M.; Sokocevic, D.; Wagner, D.E.; Coffey, A.; Antunes, M.; Robinson, K.L.; Mitsialis, S.A.; Kourembanas, S.; et al. Systemic administration of human bone marrow-derived mesenchymal stromal cell extracellular vesicles ameliorates aspergillus hyphal extract-induced allergic airway inflammation in immunocompetent mice. Stem Cells Transl. Med. 2015, 4, 1302-1316. [CrossRef] [PubMed]

91. Wang, X.; Gu, H.; Qin, D.; Yang, L.; Huang, W.; Essandoh, K.; Wang, Y.; Caldwell, C.C.; Peng, T.; Zingarelli, B.; et al. Exosomal miR-223 contributes to mesenchymal stem cell-elicited cardioprotection in polymicrobial sepsis. Sci. Rep. 2015, 5, 13721. [CrossRef] [PubMed]

92. Yang, J.; Liu, X.X.; Fan, H.; Tang, Q.; Shou, Z.X.; Zuo, D.M.; Zou, Z.; Xu, M.; Chen, Q.Y.; Peng, Y.; et al. Extracellular vesicles derived from bone marrow mesenchymal stem cells protect against experimental colitis via attenuating colon inflammation, oxidative stress and apoptosis. PLoS ONE 2015, 10, e0140551. [CrossRef] [PubMed] 